\title{
A Case of Glottic Cavernous Hemangioma Mimicking Malignancy in Elderly Patient
}

\author{
Beom Mo Koo' (D), Moon Seung Beag' (D), Min A Kim², and Seung Woo Kim ${ }^{1}$ (D) \\ Departments of ${ }^{1}$ Otorhinolaryngology-Head and Neck Surgery and ${ }^{2}$ Pathology, Veterans Health Service Medical Center, Seoul, Korea
}

악성 종물과 유사한 양상의 노령에서 발생한 성문 해면상 혈관종 1 예

구범모 ${ }^{1}$, 백문승 ${ }^{1}$, 김민아 ${ }^{2}$, 김승우 ${ }^{1}$

중앙보훈병원 ${ }^{1}$ 이비인후-두경부외과, ${ }^{2}$ 병리과

The etiology of laryngeal hemangioma is unclear, and it is classified into infant and adult types. The former is capillary hemangioma and relatively common, the latter is cavernous type and very rare. The adult laryngeal hemangioma mainly occurs in supraglottis and glottis. A 75-year-old man came to our clinic with a voice change that started four months ago. The laryngoscopic finding showed that the surface of oval-shaped mass is covered with turbid exudates. We performed the laryngeal microsurgery with $\mathrm{CO}_{2}$ laser. The mass was pathologically proven as cavernous hemangioma. We report a very rare and didactic case with review of relevant literature.

Keywords Hemangioma; Larynx; Aged.

\section{서 론}

혈관종은 원인 미상의 흔한 양성 종양으로 단일 병변으로 발생하는 경우는 두경부 영역이 $60 \%$ 로 가장 흔하다[1]. 두경부에선 구강 설, 협부 및 이하선 등에 호발하며[2], 후두에서는 비교적 드물다[1]. 전체 혈관종의 $95 \%$ 정도가 조직학적으로 모세혈관 형태 인 소아형이고, 나머지가 해면상인 성인형이다[3]. 호발 연령은 영유아기이며, 65세 이상 의 고령에서의 발생은 매우 드물다[4].

75세 남자가 내원 4개월 전부터 시작된 애성을 주소로 내원하였다. 후두 내시경 검사 에서 성문 틈의 절반 이상을 채우고 있는, 표면이 혼탁한 삼출물로 덮여 있는 타원형의 종물이 관찰되어, 레이저 후두미세수술을 시행하였고 해면상 혈관종으로 최종 진단되 었다. 저자들은 전형적인 혈관종의 내시경 소견과는 상이하며, 발생 빈도가 매우 드문 고령에서의 후두 해면상 혈관종을 경험하여 문헌고찰과 함께 보고하고자 한다.

\section{증 례}

74세 남자 환자가 내원 4개월 전부터 인지된 음성 변화를 주소로 내원하였다. 고혈압,
Received July 23, 2021

Revised August 16, 2021

Accepted August 19, 2021

\section{Corresponding Author}

Seung Woo Kim, MD

Department of OtorhinolaryngologyHead and Neck Surgery,

Veterans Health Service Medical Center, 53 Jinhwangdo-ro 61-gil, Gangdong-gu, Seoul 05368, Korea

Tel +82-2-2225-1384

Fax+82-2-2225-1385

E-mail entzzang1020@daum.net

ORCID iDs

Beom Mo Koo (D)

https://orcid.org/0000-0002-2597-1204 Moon Seung Beag (iD

https://orcid.org/0000-0003-1008-8168 Seung Woo Kim (D) https://orcid.org/0000-0002-7931-6977

This is an Open Access article distributed under the terms of the Creative Commons Attribution Non-Commercial License (https://creativecommons.org/ licenses/by-nc/4.0) which permits unrestricted non-commercial use, distribution, and reproduction in any medium, provided the original work is properly cited. 
당뇨 및 전립선 비대증 등이 있으며, 흡연력은 약 50년 전부터 금연한 상태로 1.5 갑년이며, 평소에 음주는 거의 하지 않는다 고 하였다. 중등도 이상의 신체 활동 시에 호흡곤란을 호소했 으며, 객담, 기침 및 인후두 역류 증상 등은 없었고, 경부에 저 명한 외상, 수술 및 최근 1년 이내의 전신마취 등은 부인하였 다. 경성 후두내시경 검사에서 성문의 중간 부위에서 전연합 에 걸쳐서 표면이 혼탁한 삼출물로 덮여 있는 타원형 종물이 관찰되었다(Fig. 1A). 종물은 기도의 $50 \%$ 이상을 차지하고 있었고, 호흡 시에 종물의 명확한 움직임은 없었으며, 성대 마 비는 관찰되지 않았다.

성대진동검사에서 점막 파동은 감소된 양상이었고, 성문 폐쇄는 불완전하였다. GRBAS 척도 평정법에서는 5 가지 모 두 2-3점이었고, 최장 발성 지속시간은 6.2초로 감소된 양상 이었다. 다면음성검사(Multi-Dimensional Voice Program, PENTAX Medical, Montvale, NJ, USA)에서 기본 주파수가 $285.25 \mathrm{~Hz}$, 주파수변동률(jitter)은 $6.36 \%$ (참고치 < $1.1 \%$ ), 진 폭변동률(shimmer)은 $15.02 \%$ (참고치 <3.8\%), 잡음 대 배음 비(noise to harmonic ratio)는 0.552 (참고치 <0.2) 등으로 주 요 지표가 매우 증가된 소견이었다. 종물을 평가하기 위해 시 행한 컴퓨터단층촬영에서 성문부에 부분적으로 조영증강되 는 $1.4 \times 1.1 \mathrm{~cm}$ 크기의 타원형 연조직 음영이 관찰되었으며, 비정상적인 림프절의 비대 소견은 없었다(Fig. 2). 조직검사를 위해 시행한 굴곡형 후두내시경 유도 하 생검에서는 비정형 세포와 경한 이형성증 등으로 보고되었다. 이상의 소견 등을 종합하여 악성 종물의 가능성을 포함한 후두 종물로 평가하 고, 레이저 후두미세수술을 계획하였다.

구강 삽관 시 종물의 파종이 우려되어 기관절개술을 먼저 시행하고, 기관 절개창으로 레이저용 기관삽관 튜브를 삽입하 였다. 현수 후두경 거치 후에 관찰한 종물의 표면은 혼탁한 삼 출액으로 덮여 있었으며, 종물을 겸자로 가동시켰을 때 좌측 보다 우측 진성대에 더 넓게 위치하는 것이 확인되었다. 지속 슈퍼펄스 방법으로 3와트 강도의 $\mathrm{CO}_{2}$ 레이저(Acupulse, $\mathrm{Lu}^{-}$ menis Ltd. Yokneam, Israel)를 사용하여 수술하였다. 악성 의 가능성을 배제할 수 없어 종물 주변 조직으로 일정한 절제

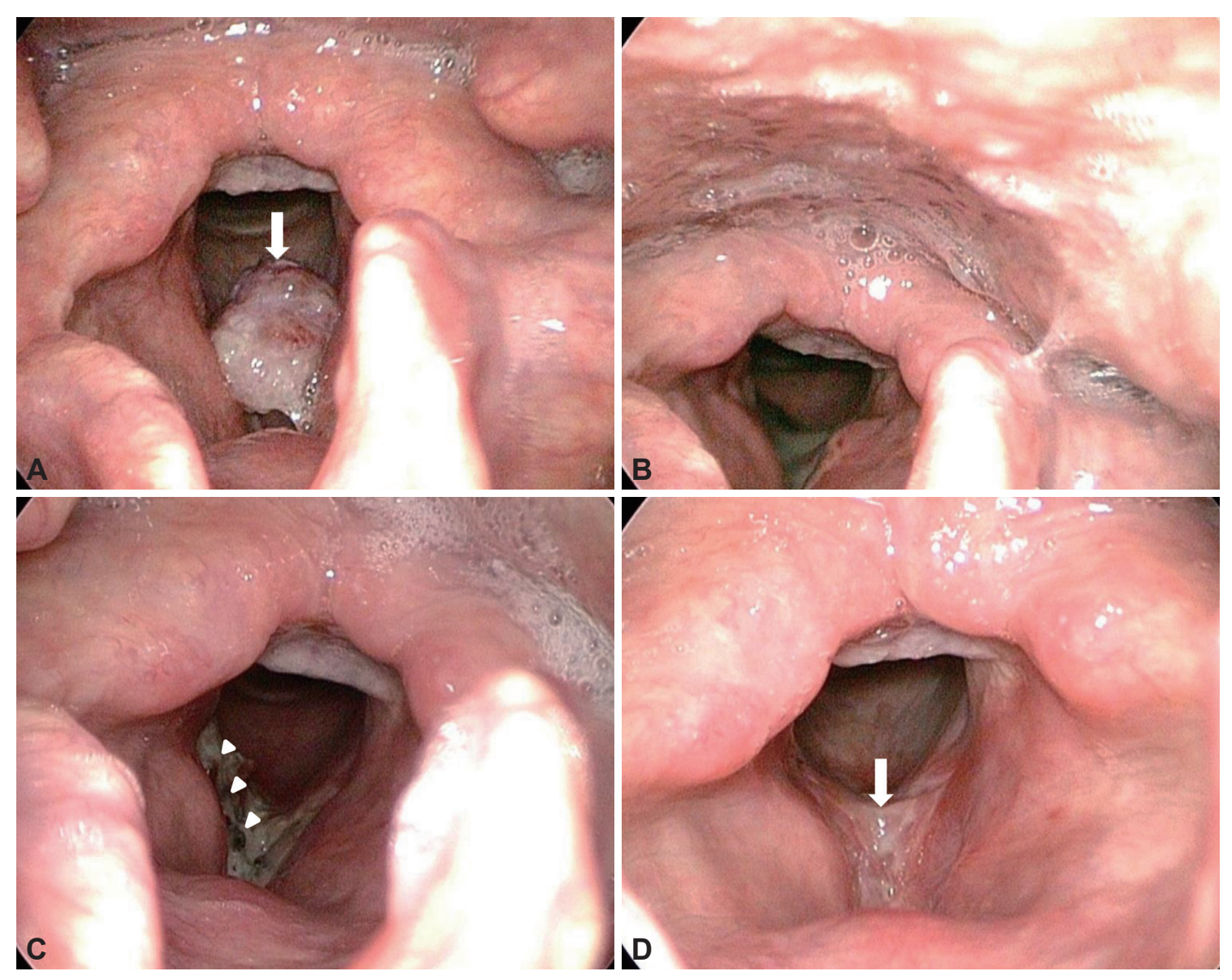

Fig. 1. The rigid laryngoscopic findings. A: It shows about $1.5 \times 1.0 \mathrm{~cm}$ sized oval shaped mass covered with turbid exudates on the surface (arrow). B: At the postoperative one day, there is no bleeding and only tissue fluids are observed in the operation site. C: At the postoperative one week, some granulation tissues are observed in the both true vocal folds and subglottis (arrowheads). D: One month after surgery, it shows glottic web formation (arrow). 
연을 두면서 겸자로 종물의 주변 점막을 잡고 절제하였다. 종물의 절제 중간과 직후 모두에서 출혈이 잘 발생하여 레이 저와 전기 소작기 등을 이용하여 지혈하였으며, 술 중 동결절 편 검사는 시행하지 않았다. 종물의 절제 이후에 평가한 기 시부는 우측 진성대의 절반 이상, 전연합 및 좌측 진성대의 전방 $1 / 3$ 등이었다.

술 후 1 일째 후두내시경에서 종물의 절제 범위가 잘 관찰되 며, 출혈 소견은 없었다(Fig. 1B). 술 후 2일째 출혈 및 호흡곤 란 등이 없어서 기관창을 봉합하였고, 술 후 1 주째의 내시경 검사에서는 수술 부위에 육아 조직이 관찰되었다(Fig. 1C). 이 런 소견이 확인된 직후 기존에 사용하던 양성자 펌프 차단제 외에 구강 스테로이드 흡입제를 추가하였다. 적출물의 병리소 견은 저배율에서 이형성이 없는 정상 편평상피세포가 표피 아
래 방향으로 증식하고 있으며(Fig. 3A), 중배율에서는 늘어난 혈관은 얇은 벽을 가지며, 내부에는 많은 적혈구와 혈전 등이 관찰되어 해면상 혈관종으로 최종 진단되었다(Fig. 3B).

술 후 4주에 외래에서 시행한 후두 내시경 검사에서는 전 연합 부위에 성문 격막(glottis web)이 관찰되었고(Fig. 1D), 술 후 6주에 시행한 음성평가에서는 주요 음성 지표에서 술 전 보다 악화된 소견이었다. 환자는 심한 신체 활동 시에만 호 흡곤란을 호소하였고, 일상생활에 큰 지장은 없다고 하였다. 성문 격막에 대한 수술적 치료는 술 후의 빈번한 재발 및 추 가 전신마취에 대한 환자의 거부 등으로 시행하지 못했고, 술 후 13 개월이 지난 현재까지 종물의 재발은 없으며, 성문 격막 은 이전과 비슷한 양상으로 추적 관찰 중이다.
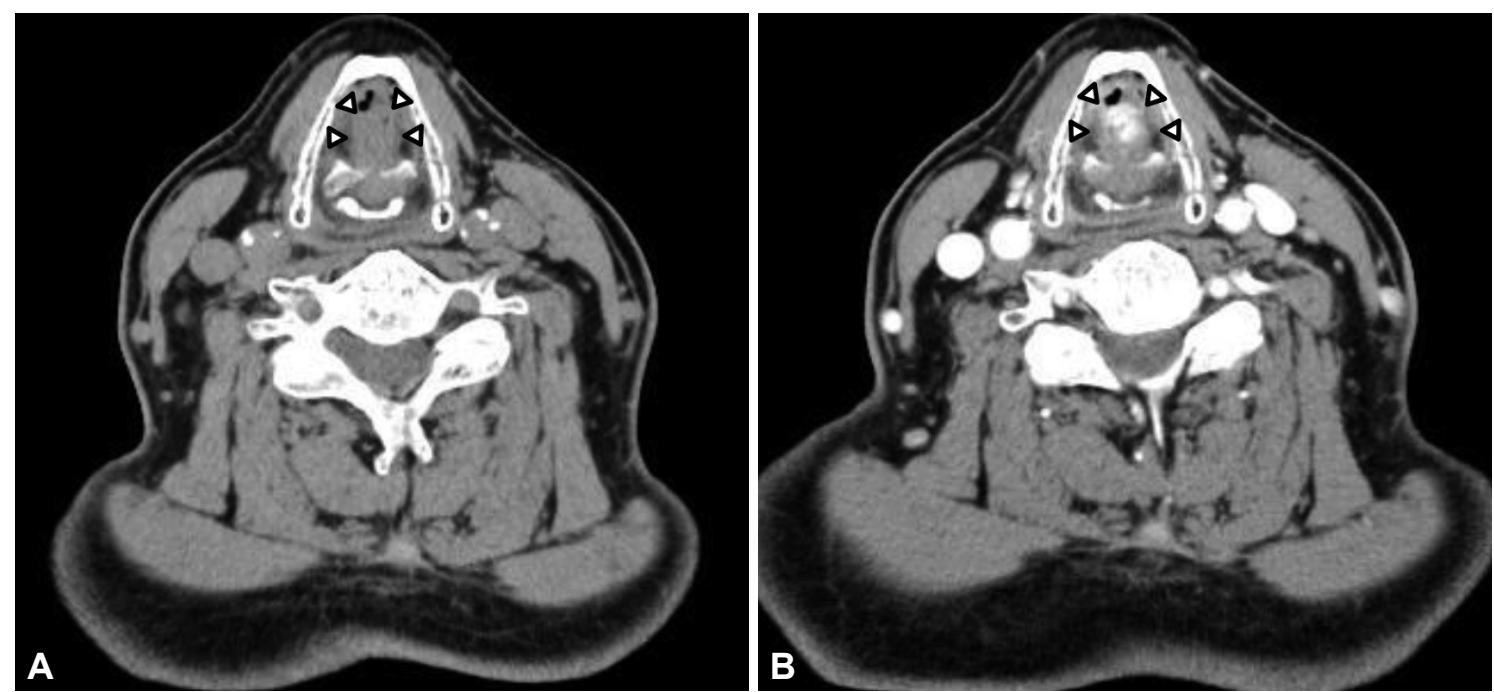

Fig. 2. The neck computed tomography (CT) scans. A: Non-enhanced axial CT scan shows $1.4 \times 1.1 \mathrm{~cm}$ sized oval-shaped soft tissue density in anterior glottic area (arrowheads). B: Enhanced axial CT scan shows same sized heterogenous enhanced mass in anterior glottic area (arrowheads).
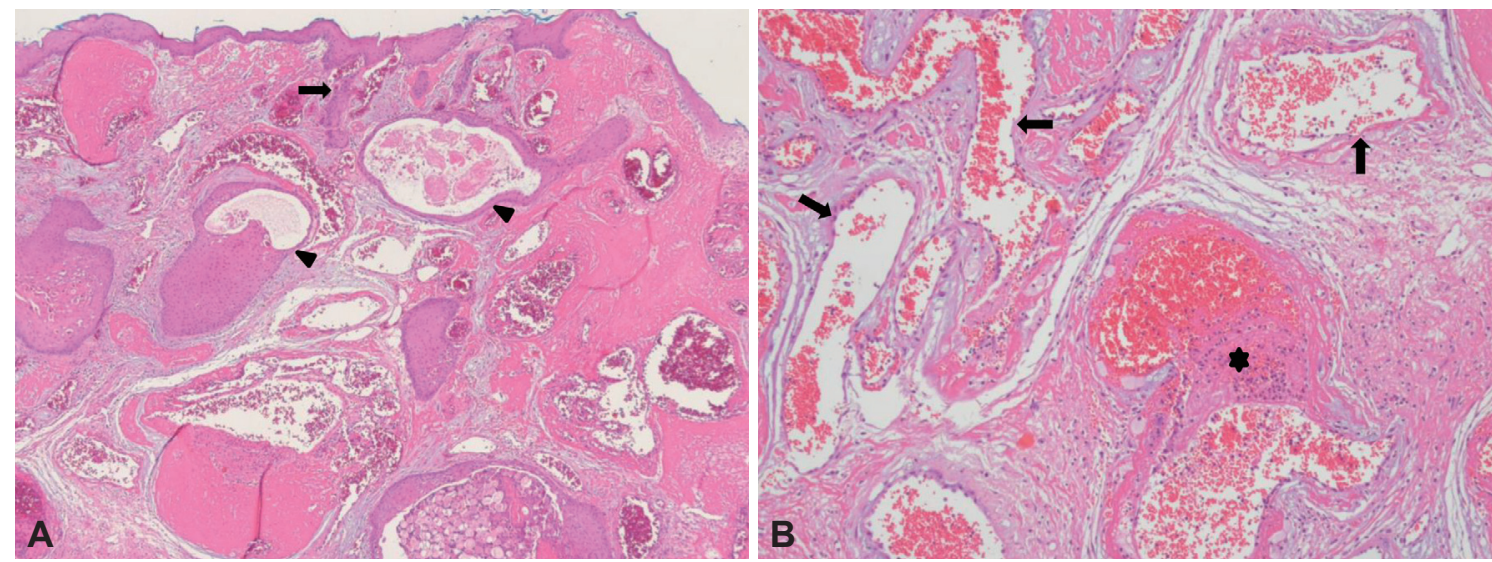

Fig. 3. The microscopic findings of specimen. A: It shows normal squamous epithelial cells without dysplasia are proliferating down the epidermis (arrow), and epithelial cells that are not connected to the epidermis are observed, so they look similar to epithelial cell carcinoma (arrowheads) (hematoxylin and eosin [HE] staining, $\times 40$ ). B: The other photo shows enlarged blood vessels are surrounded by a single layer of vascular endothelial cells and have a thin wall (arrows). In addition, there are many red blood cells inside the blood vessels, and thrombi are also observed (asterisk) (HE staining, $\times 100$ ). 


\section{고 찰}

혈관종은 인체의 모든 부위에서 흔하게 발견되는 양성 종 양으로, 대부분 선천적으로 발생하며, 그 외에 과오종, 혈류 이상 및 국소 외상 등에 의해서도 발생할 수 있다[5]. 발생 시 기에 따라 소아형과 성인형으로 구분되며, 조직학적으로는 모세상, 해면상 및 혼합형 등으로 구분할 수 있다[3]. 혈관직 경이 $140 \mu \mathrm{m}$ 보다 작은 경우는 모세상, 이보다 큰 경우는 해 면상으로 분류된다[4]. 두경부 영역에서 $60 \%$ 정도 발생하며 특 히 구강, 비강, 이하선 및 설 등에 호발하고, 후두에서는 비교 적 드물며[5], 두경부의 근육 내에 발생하는 경우는 교근과 승 모근 등에 잘 발생한다[2]. 영유아 시기의 후두 혈관종은 대 부분 모세상으로 주로 성문 하부에 발생하지만[3], 자연 소실 에 빈번하여 5 세 이후에는 $1.6 \%$ 정도만 관찰되나, 12 세 이후 에는 자연 소실을 기대하기 힘들다[6]. 성인 혈관종은 대부분 해면상으로 성문 상부 및 성문부 등에 호발하며, 소아에 비해 매우 드물고, 65세 이상에서는 더욱 드물다[4]. 해면상 혈관종 의 전형적인 내시경 소견은 유경성의 경계가 분명한 검푸른색 의 종양으로[3], 본 증례는 이와는 다른 양상이었다. 증상은 무 증상부터 객혈, 호흡곤란 등으로 다양하게 나타나고, 성인은 피부 병변이 잘 동반되는 않는다[3].

후두 혈관종의 보고는 드물어서 국내에서는 1998년 가성대 와 피열 후두개 주름 부위의 발생이 처음 보고된 이후[7], 진 성대 2예[8,9], 이상동 1예[1], 피열부 1예[5] 등이 있으나, 본 증 례와 같이 70세 이상에서의 발생은 최근까지 보고가 없었다. 자연 소실이 드문 성인형 후두 혈관종은 $\mathrm{CO}_{2}$ 레이저를 이용 한 후두미세수술로 종물을 완전히 절제하는 것이 원칙이다 [10]. 그러나 종물이 큰 경우는 불완전 절제 및 정상 조직의 과도한 절제 등으로 인하여 술 후 기도 협착 또는 격막 등의 합병증을 유발할 수 있다[11].

본 증례는 후두경 소견이 일반적인 혈관종과 상이하고, 술 전 조직검사에서의 이형성증 양상 및 영상검사에서의 조영 증강 소견 등으로 인하여, 악성 종물의 가능성도 염두에 두 고 주변 조직을 포함해서 절제하였다. 후향적으로 생각해 보 면 동결절편 검사에서 혈관성 또는 양성 종물 등으로 보고되 었으면 좀 더 보존적인 수술이 가능해서 술 후 합병증 발생 의 가능성이 감소할 수 있었을 것 같다. 술 전에 너무 악성의 가능성을 염두에 두었고, 또 수술 소요 시간 등을 고려해서 동결절편검사를 시행하지 않았다. 또한 절제 중간과 직후에 출혈이 심하여 레이저와 전기 소작기 등을 사용하면서, 비교 적 넓은 부위의 조직에 손상을 준 점과 술 후 미흡한 음성 안 정 등이 성문 격막의 형성에 기여하였다고 생각된다. 후두미 세수술 이외의 접근법으로는 종물이 매우 큰 경우는 측인두
절개술을 시행할 수 있으며[3], 최근에는 경구강 로봇 보조 하 수술로 미용학적 및 기능적으로 우수한 결과를 보이고 있 다[12].

저자들은 본 증례를 통해서 성인형, 특히 고령에서의 후두 혈관종은 빈도가 매우 드물지만 이학적 및 내시경 소견 등에 서 전형적인 성상과는 다르게 보일 수 있다는 경험을 하였다. 혈관종의 술 전 조직 검사는 출혈 및 기도 폐색 등의 가능성 때문에 위험할 수 있고, 술 중 동결절편 검사가 진단에 유용 할 수 있다. 또한 양측 진성대에 기저부를 두고 있는 종물을 수술하는 경우에는 종양의 성상에 따른 적절한 절제 범위의 결정, 세심한 조직 조작 및 술 후 적절한 음성 안정 등이 후두 협착 및 격막 등과 같은 합병증의 발생 빈도를 감소시킬 수 있 다는 교훈을 얻었다.

중심 단어: 혈관종; 후두; 고령.

Acknowledgments,

None.

Conflicts of Interest

The authors have no financial conflicts of interest.

Authors' Contribution

Conceptualization: Seung Woo Kim. Data curation: Moon Seung Beag. Formal analysis: Moon Seung Beag. Investigation: Moon Seung Beag. Methodology: Beom Mo Koo. Resources: Min A Kim. Supervision: Seung Woo Kim. Visualization: Min A Kim. Writing_original draft: Beom Mo Koo, Min A Kim. Writing—review \& editing: Seung Woo Kim.

\section{REFERENCES}

1. Guo YC, Chu PY, Ho DM, Chang SY. Hemangioma of the pyriform sinus. Otolaryngol Head Neck Surg 2001;124(6):707-8.

2. Yeo CK. Cavernous hemangioma of the masseter muscle. Korean J Otorhinolaryngol-Head Neck Surg 2006;49(6):669-71.

3. Kim HS. Benign laryngeal disorders. Korean J OtorhinolaryngolHead Neck Surg 2013;56(6):332-8.

4. Moon JH, Hwang DJ, Kim JS, No HS, Lee SE, Kim SH, et al. Clinical study of the hemangioma of the head and neck in adult. Korean J Otorhinolaryngol-Head Neck Surg 2000;43(8):878-82.

5. Kim TH, Kim SY, Lee SH, Jin SM. A case of cavernous hemangioma occurred in arytenoid. J Korean Soc Laryngol Phoniatr Logop 2015; 26(1):54-7.

6. Waner M, Suen JY, Dinehart S. Treatment of hemangiomas of the head and neck. Laryngoscope 1992;102(10):1123-32.

7. Cho SH, Kim HT, Kim MS, Sun DI, Lee DH, Jung MK, et al. The nonsquamous cell tumors of the larynx. Korean J Otorhinolaryngol-Head Neck Surg 1998;41(7):918-24.

8. Lee JH, Park DJ, Lee JB, Kim SG. A case of cavernous hemangioma arising from left vocal cord. Korean J Otorhinolaryngol-Head Neck Surg 2007;50(6):556-9.

9. Jeon EJ, Park YS, Lee SK, Kim DK. A case of vocal cord hemangioma. J Korean Soc Laryngol Phoniatr Logop 2004;15(1):52-4.

10. Fageeh N, Manoukian J, Tewfik T, Schloss M, Williams HB, Gaskin D. Management of head and neck lymphatic malformations in children. J Otolaryngol 1997;26(4):253-8. 
11. Cotton RT, Tewfik TL. Laryngeal stenosis following carbon dioxide laser in subglottic hemangioma. Report of three cases. Ann Otol Rhinol Laryngol 1985;94(5 Pt 1):494-7.
12. Wang WH, Tsai KY. Transoral robotic resection of an adult laryngeal haemangioma and review of the literature. J Laryngol Otol 2015;129(6): 614-8. 